\title{
PENERAPAN METODE SURVEY QUESTION READ RECITED REVIEW (SQ3R) TERHADAP KEMAMPUAN MEMBACA PEMAHAMAN SISWA PADA MATA PELAJARAN BAHASA INDONESIA KELAS III SDN 05 PEMUAR
}

\author{
SafarunitaWahyuni Reski ${ }^{1}$, Mastiah $^{2}$, Yumi Sarassanti ${ }^{3}$ \\ ${ }^{1}$ Mahasiswa Lulusan Program Studi PGSD \\ ${ }^{2,3}$ Dosen STKIP Melawi
}

Jln. RSUD Melawi, Nanga Pinoh, Kabupaten Melawi, Kalimantan Barat 79672

Email : $\underline{\text { safawr165@gmail.com, mastiah2011@gmail.com, yumisarassanti@yahoo.co.id }}$

\begin{abstract}
This study aims to determine differences in reading comprehension skills in Indonesian subjects before and after using the Method Question Read Recited Review Survey (SQ3R) for students in the SDN 05 Pemuar. This research is an experimental study using thePretest-Posttest One-Group Design. The population in this study included all third gradestudents of SDN 05 PEMUAR with a sample of 14 people consisting of 9 male students and 5 female students. The sample used in this study is a saturated sample, therefore all members of the population are sampled. The preliminary data of this study usedavaluepretest with an average of 61.75 and an averagescore of posttest70.35. Based on the results of research tests of reading comprehension of students' understanding shows the value of t count of 49.571 and t table of 42.048 so that Ho is rejected and Ha is accepted because $t$ count> from $t$ table. So it can be concludedthat with the Method it Question Read Recited Review Survey (SQ3R) has been proven effective against students' reading comprehension abilities, especially in class III SDN 05 Pemuar. Theresultsposttest show students' reading comprehension ability using the Survey Question Read Recited Review Method (SQ3R) higher than before being treated with the Method Question Read Recited Review Survey (SQ3R).
\end{abstract}

Keywords: comprehension reading skills, Indonesian and Question Read Recited ReviewMethod(SQ3R).

\begin{abstract}
Abstrak: Penelitian ini bertujuan untuk mengetahui perbedaan kemampuan membaca pemahaman pada matapelajaran Bahasa Indonesias ebelum dan sesudah menggunakan Metode Survey Question Read Recited Review (SQ3R) pada siswa SDN 05 PEMUAR. Penelitian ini adalah peneletian eksperimen dengan menggunakan design One-Group Pretest-Posttest. Populasi dalam penelitian ini mencakup seluruh siswa kelas III SDN 05 Pemuar dengan jumlah sampel 14 orang yang tediri dari 9 orang siswa laki-laki dan 5 orang siswa perempuan. Sampel yang dipakai dalam penelitian ini adalah sampel jenuh, maka dari itu semua anggota populasi dijadikan sampel. Data awal penelitian ini menggunakan nilai pretest dengan rata-rata 61,75 dan rata-rata nilai posttest 70,35. Berdasarkan hasil penelitian tes kemampuan membaca pemahaman siswa menunjukan nilai t hitung sebesar 49,571 dan t tabel sebesar 42,048 sehingga Ho ditolak dan Ha diterima karena t hitung $>$ dari t tabel. Jadi dapat disimpulkan bahwa dengan Metode Survey Question Read Recited Review (SQ3R) terbukti
\end{abstract}




\section{Bestari: Jurnal Pendidikan dan Kebudayaan \\ Volume 1 Nomor 2 Oktober 2020}

efektif terhadap kemampuan membaca pemahaman siswa khususnya di kelas III SDN 05 Pemuar. Hasil posttest menunjukan kemampuan membaca pemahaman siswa dengan menggunakan Metode Survey Question Read Recited Review (SQ3R) lebih tinggi darisebelumdiberiperlakuandenganMetodeSurvey Question Read Recited Review (SQ3R).

Kata Kunci: kemampuan membaca pemahaman, Bahasa Indonesia dan MetodeSurvey Question Read Recited Review (SQ3R).

$\mathrm{M}$ embaca pemahaman adalah suatu proses yang bersifat fisik dan mental. Membaca pemahaman pada tingkat sekolah dasar, khususnya pada murid kelas III menjadi bagian yang terpisahkan dari prinsip-prinsip membaca secara umum, yaitu sebagai berikut: (1) membaca bukanlah hanya mengenal dan menyembunyikan huruf tetapi kegiatan membaca melampaui pengenalan huruf dan bunyi. (2) membaca dan menguasai Bahasa terjadi secara bersamaan. (3) seseorang tidak dapat di katakana mempunyai keterampilan membaca jika ia tidak menguasai Bahasa. (4) membaca dan berfikir terjadi secara bersamaan, seseorang tidak dapat membaca tanpa mempergunakan pikiran dan perasaannya. (5) membaca berarti memahami, ini berarti membaca berakhir pada pemahaman (Aminuddin dalam Artu N, 2008).

Berdasarkan observasi yang peneliti lakukan di kelas III SDN 05 Pemuar pada tanggal 12-16 Februari
2019, penelitian menemukan permasalahan-permasalahan yang terjadi di dalam kelas ketika proses pembelajaran, yaitu guru sering mengalami kendala-kendala dalam proses pembelajaran, terutama pada pembelajaran Bahasa Indonesia. Kendala yang paling sering terjadi adalah kurangnnya pemahaman membaca siswa dikarenakan ada satu siswa belum lancar membaca dan sebagian siswa kurang fokus dalam proses pembelajaran, dari 14 siswa ada 4 siswa yang bisamenjawabpertanyaan dan 10 siswa tidak bisa menjawab pertanyaan dari guru ketika proses pembelajaran, siswa kurang memperhatikan saat guru menyampaikan materi, kurangnya penggunaan media sebagai alat penunjang pada proses pembelajaran, kemampuan membaca pemahaman siswa masih kurang.

Hasil observasi di atas menunjukkan beberapa kesenjangan yang mengakibatkan masih kurangnya 


\section{Bestari: Jurnal Pendidikan dan Kebudayaan}

Volume 1 Nomor 2 Oktober 2020

kemampuan membaca pemahaman siswa sehingga berpengaruh pada pemahaman mereka terhadap bacaan. Dari permasalahan tersebut solusi yang dapat digunakan untuk memecahkan masalah atau kendala yang ditemukan dalam proses pembelajaran mengenai kemampuan membaca pemahaman siswa pada pembelajaran Bahasa Indonesia seperti yang dialami oleh guru yaitu menggunakan Metode Survey Question Read Recited Review (SQ3R). Hal ini dapat dibuktikan oleh Nurrina Dyah Pupita mahasiswa prodi PGSD Universitas Negeri Yogyakarta dengan judul pengaruh Metode Survey Question Read Recited Review (SQ3R) terhadap kemampuan membaca pemahaman siswa kelas IV SDN Muhammadiyah.

\section{Survey Question Read Recited} Review (SQ3R) merupakan metode pemahaman yang membantu siswa berpikir tentang teks yang sedang mereka baca. Sering kali dikategorikan sebagai metode belajar, SQ3R membantu siswa "mendapatkan sesuatu" ketika pertama kali mereka membaca teks (Huda, 2013:244). Ada beberapa keunggulan dari metode $S Q 3 R$ ialah (1) siswa diarahkan untuk terbiasa berfikir terhadap bahan bacaan sehinga siswa menjadi lebih aktif dan terlatih untuk terbiasa membuat pertanyaan, (2) siswa berusaha untuk memikirkan jawaban-jawaban dari pertanyaan yang mendalami isi bacaan atau teks tersebut, (3) siswa dapat bekerjasama dalam kelompoknya untuk saling bertukar pendapat dalam memahami konsep materi yang disajikan dalam uraian teks.

Maka dengan adanya kendala yang ditemukan, peneliti menawarkan metode $S Q 3 R$ untuk mengatasi masalah tersebut dengan memberikan perbandingan kemampuan membaca pemahaman sebelum diterapkan metode $S Q 3 R$ siswa pada mata pelajaran pendidikan Bahasa Indonesia akan menjadi lebih baik setelah diterapkan metode $S Q 3 R$. Peneliti yakin bahwa dengan metode $S Q 3 R$ bisa meningkatkan kemampuan membaca pemahaman siswa di SDN 05 Pemuar menjadi alasan peneliti untuk melakukan penelitian eksperimen yang berjudul "Penerapan Metode Survey Question Read Recited Review (SQ3R) Terhadap Kemampuan Membaca Pemahaman Pada Mata Pelajaran Bahasa Indonesia Siswa Kelas III SDN 05 Pemuar".

Tujuan dari penelitian ini adalah untuk mengetahui pengaruh dari metode $S Q 3 R$ terhadap kemampuan membaca 


\section{Bestari: Jurnal Pendidikan dan Kebudayaan}

Volume 1 Nomor 2 Oktober 2020

pemahaman siswa pada mata pelajaran Pendidikan Bahasa Indonesia.

\section{Metode Penelitian}

Dalam peneltian ini metode yang digunakan adalah metode penelitian kuantitatif. Penelitian kuantitatif dapat diartikan sebagai metode penelitian yang berlandaskan pada filsafat positivisme, digunakan untuk meneliti pada populasi dan sampel tertentu, pengumpulan data menggunakan instrument penelitian, analisis data bersifat kuantitatif/statistik, dengan tujuan untuk menguji hipotesis yang telah ditetapkan (Sugiyono, 2017:109). Penelitian kuantitatif adalah suatu penelitian yang dipakai untuk menguji suatu teori, menyajikan suatu fakta, atau mendeskripsikan statistik dan menunjukan hubungan antar variable dan mengembangkan pemahaman atau mendeskripsikan banyak hal.

Desain yang digunakan dalam penelitian ini adalah Pre-Experimental Design dengan tipe One-Group Pretest-Posttest Design. One-Group Pretest-Posttest Design merupakan sebuah desain penelitian yang digunakan dengan cara memberikan tes awal dan tes akhir terhadap sampel penelitian kelompok tunggal (Arikunto, 2014:67).

Populasi adalah wilayah generalisasi yang terdiri atas obyek atau subyek yang mempunyai kualitas dan karakteristik tertentu yang ditetapkan oleh peneliti untuk mempelajari dan kemudian ditarik kesimpulan (Sugiyono, 2017:117). Jadi populasi dalam penelitian ini adalah semua siswa kelas III SDN 05 Pemuar yang berjumlah 14 orang siswa. Sampel adalah bagian dari jumlah dan karakteristik yang dimiliki oleh populasi (Sugiyono, 2017:118).

Sampling jenuh adalah teknik penentuan sampel bila semua anggota populasi digunakan sebagai sampel. Hal ini dilakukan bila jumlah populasi relative kecil. Jadi sampel dalam penelitian ini adalah siswa kelas III SDN 05 Pemuar berjumlah 14 siswa dijadikan sampel penelitian, yaitu terdiri dari 9 siswa laki-laki dan 5 siswa perempuan

Penelitian ini dilaksanakan di SDN 05 Pemuar Kecamatan Belimbing, Kabupaten Melawi, Propinsi Kalimantan Barat pada semester genaptahunajaran 2019 dikelas III SDN 05 Pemuar.

Arikunto (2014:100) mengatakan "Teknik pengumpulan data adalah cara-cara yang dapat dipergunakan oleh peneliti untuk mengumpulkan data". Teknik pengumpulan data merupakan yang paling utama dalam penelitian, karena tujuan dari penelitian ini adalah 


\section{Bestari: Jurnal Pendidikan dan Kebudayaan \\ Volume 1 Nomor 2 Oktober 2020}

untuk mendapatkan data. Teknik yang digunakan dalam pengumpulan data adalah tes kemampuan membaca siswa melalui tes tertulis. Dalam penelitian ini, instrumen yang digunakan peneliti yaitu dalam bentuk observasi dan tes.

Observasi dapat mengukur atau menilai hasil dan proses belajar misalnya tingkah laku siswa waktu belajar, tingkah laku guru waktu mengajar, kegiatan diskusi siswa, partisipasi siswa dalam simulasi.

Tes dalam penelitian ini dilakukan untuk mengukur seberapa besar kemampuan membaca pemahaman siswa tentang pelajaran Bahasa Indonesia. Adapun tes yang digunakan dalam penelitian ini adalah tes tertulis yaitu dalam bentuk soal esay. Instrumen dalam penelitian ini menggunakan lembar tes yaitu tes tertulis. Soal yang dibuat sebanyak 10 soal. Tes dilaksanakan berupa tes tertulis sebelum perlakuan (pretest) dan sesudah perlakukan (posttest) untuk mengetahui pemahaman siswa terhadap pelajaran bahasa Indonesia.

\section{Hasil dan Pembahasan}

Berdasarkan hasil penelitian dapat dilihat dari rata-rata kemampuan membaca pemahaman siswa sebelum dan sesudah perlakuan adalah berbeda.
Dengan demikian dapat dinyatakan bahwa setelah mendapatkan perlakuan dengan menggunakan metode SQ3R berpengaruh terhadap kemampuan membaca pemahaman siswa SDN 05 Pemuar.

Penelitian ini dilaksanakan di SDN 05 Pemuar selama 2 hari dalam kurun waktu 1 minggu. Subjek dalam penelitian ini adalah siswa kelas III yang berjumlah 14 orang, dan objek dalam penelitian inia dalah penerapan metode SQ3R terhadap kemampuan membaca pemahaman siswa. Sebelum melakukan penelitian terlebih dahulu dilakukan uji coba soal yang akan dijadikan sebagai acuan soal pretest maupun posttest.

Tahap awal dari penelitian, peneliti melakukan penyusunan instrumen yang akan digunakan dalam penelitian. Instrumen pada penelitian ini yaitu berupa soal pretest dan posttest, soal tersebut digunakan untuk mengukur tingkat pemahaman siswa terhadap pembelajaran yang telah diberikan.

Untuk mendapatkan instrumen yang baik maka diperlukan pengujian pada instrumen-instrumen yang akan digunakan. Soal yang dibuat berupa esai yang berjumlah 10 soal pretest dan 10 soal posttest. sebelum soal-soal digunakan, peneliti terlebih dahulu 


\section{Bestari: Jurnal Pendidikan dan Kebudayaan}

Volume 1 Nomor 2 Oktober 2020

melakukan pengujian validitas soal dengan Teknik pearson kolerasi product moment dengan menggunakan program SPSS versi 17.

Pada uji validitas dilakukan dengan Batasan $r$ table dengan nilai signifikansi 0,553 . dari perhitungan uji validitas diperoleh 5 soal pretest dan 5 soal posttest yang valid. Uji instrumen selanjutnya yaitu uji reabilitas. Soal yang diuji reabilitasnya yaitu soal yang dinyatakan valid. Pengujian reabilitas dilakukan dengan menggunakan Cronbach alpha< $\mathrm{r}$ tabel maka soal dinyatakan reliabel.

Proses selanjutnya yaitu kegiatan inti dari penelitian adalah proses pembelajaran. Peneliti memberikan soal pretest kepada siswa tanpa perlakuan. kemudian setelah dua hari selanjutnya peneliti memberikan pelajaran dengan menggunakan metode SQ3R setelah itu peneliti memberikan soal posttest untuk mengetahui kemampuan membaca pemahaman siswa setelah mendapat perlakuan dengan menggunakan metode SQ3R.

$\begin{array}{lr}\text { Selama proses pembelajaran } \\ \text { peneliti menemukan } & \text { beberapa } \\ \text { permasalahan yaitu } & \text { pemahaman } \\ \text { membaca siswa masih kurang pada saat } \\ \text { peneliti menyuruh siswa membaca teks }\end{array}$

yang ada pada buku, sebagian siswa kurang fokus saat proses pembelajaran dan siswa kurang memperhatikan saat peneliti menyampaikan materi maka dari itu untuk mengatasi permasalahan tersebut, peneliti berinisiatif untuk melakukan pendekatan dengan memberikan dan ngulang-ulang bacaan yang telah dibaca untuk melatih daya ingat siswa dan pemahaman siswa pada teks bacaan.

\section{Kemampuan} membaca pemahaman siswa setelah diterapkan metode SQ3R lebih tinggi dari pada kemampuan pemahaman membaca siswa sebelum memdapat perlakuan. Hal ini terlihat dari nilai rata-rata posttest siswa 70,35 sedangkan rata-rata pretest 61,75. Dapat disimpulkan kemampuan membaca pemahaman siswa setelah mendapat perlakuan meningkat dibandingakan dengan sebelum diberi perlakuan.

Data kemampuan membaca pemahaman siswa selanjutnya dilakukan pengujian prasyarat analisis. Uji prasyarat analisis yang pertama yaitu uji deskriptif untuk mengetahui meningkanya data sebelum dan sesudah perlakuan. Pengujian deskriptif pada penelitian ini menggunakan uji descriptive statistics dengan 


\section{Bestari: Jurnal Pendidikan dan Kebudayaan}

Volume 1 Nomor 2 Oktober 2020

menggunakan program SPSS Versi 17.

Uji prasyarat analisis yang kedua yaitu uji normalitas data untuk mengetahui data tersebut berdistribusi normal atautidak. Uji normalitas data dalam penelitian ini menggunakan program SPSS Versi 17.

Berdasarkan pengujian normalitas data dengan menggunakan One Sample Kolmogorov Smirnov Test didapatkan hasil t hitung> 0,05. Karena data yang diperoleh berdistribusi normal maka uji analisis dilanjutkan dengan uji hipotesis menggunakan uji One Sample T-Test deng program SPSS Versi 17.

Berdasarkan hasil perhitungan karena nilai $t$ hitung $>t$ table maka dapat disimpulkan bahwa Ho ditolak, artinya rata-rata kemampuan membaca pemahaman siswa sebelum dan sesudah perlakuan adalah berbeda. Dengan demikian, dapat dinyatakan bahwa setelah mendapat perlakuan dengan SQ3R terdapat pengaruh terhadap kemampuan membaca pemahaman siswa. Jadi dapat disimpulkan bahwa terdapat perbedaan kemampuan membaca pemahaman siswa sebelum dan sesudah mendapat perlakuan dengan Metode SQ3R. dari perhitungan tersebut pembelajaran dengan menggunakan Metode SQ3R terbukti efektif dalam memaksimalkan kemampuan membaca pemahaman siswa kelas III SDN 05 Pemuar.

\section{SIMPULAN}

Dari hasil analisis di atas dapat disimpulkan bahwa kemampuan membaca pemahaman siswa sebelum penerapan SQ3R dengan jumlah siswa 14 orang diperoleh hasil 61,75. Kemampuan membaca pemahaman siswa sesudah penerapan Metode SQ3R dengan jumlah siswa 14 orang diperoleh 70,35 .

Berdasarkan uji hipotesis, maka Ho ditolak dan Ha diterima. Karena nilai signifikansi<0,05. Jadi dapat disimpulkan bahwa terdapat perbedaan yang signifikan kemampuan membaca pemahaman siswa antara sebelum dan sesudah diberi perlakuan dengan Metode SQ3R dari hasil uji hipotesis melalui program SPSS Versi 17. Metode SQ3R terbukti efektif digunakan di kelas III SDN 05 Pemuar.

\section{Daftar Pustaka}

Arikunto, S. 2014. Metodologi Penelitian Pendidikan Kuantitatif dan Kualitatif. Jakarta: Renaka Cipta.

Artu, N. 2008. "Upaya Meningkatkan Kemampuan Membaca Pemahaman Siswa Kelas IV SDN 


\section{Bestari: Jurnal Pendidikan dan Kebudayaan \\ Volume 1 Nomor 2 Oktober 2020}

Pembina Liang".Jurnal Kreatif

Tadulako Online, Volume 2 No.

2.Fakustas Keguruan dan Ilmu

Pendidikan Universitas Tadulako.

Huda, M. 2013. Model-Model

Pengajaran dan Pembelajaran.

Yogyakarta: PusakaPelajar.

Sugiyono. 2017. Metode Penelitian

Pendidikan (Pendekatan

Kuantitatif, Kualitatif, dan $R \& D$ ).

Bandung: Alfabeta.

Tarigan, H. G. 2008. Membaca Sebagai

Suatu Keterampilan Berbahasa.

Bandung: Angkasa. 